\title{
SECOND SYMPOSIUM IN APPLIED MATHEMATICS
}

The Second Annual Symposium in Applied Mathematics of the American Mathematical Society was held at The Massachusetts Institute of Technology, Cambridge, Massachusetts, Thursday to Saturday, July 29-31, 1948. The subject of the Symposium was Electromagnetic theory. The following 232 persons, including 133 members of the Society, registered:

J. C. Abbott, Charles Adams, P. L. Alger, W. P. Allis, Willis Altar, W. S. Ament, Richard Arnowitt, N. N. Aronszajn, H. A. Baerwald, E. W. Banhagel, Shepard Bartnoff, P. F. Bartunek, R. H. Battin, R. E. Beam, E. G. Begle, D. L. Benedict, H. S. Bennett, W. R. Bennett, Stefan Bergman, C. A. Bergren, Madeleine Berthaud, E. W. Beth, M. L. Boas, R. P. Boas, H. W. Bode, E. M. Boggs, F. W. Boggs, F. E. Bothwell, George Bott, J. G. Brainerd, F. R. Britton, H. K. Brown, C. T. Bumer, E. R. Caianiello, E. B. Callahan, P. G. Carlson, J. W. Carr, G. F. Carrier, Nicholas Chako, L. G. Chelius, Jack Chernick, Peter Chiarulli, R. A. Chipman, R. V. Churchill, S. B. Cohn, Robert Corb6, S. H. Crandall, P. D. Crout, E. H. Cutler, P. B. Daitch, D. A Darling, H. C. Davis, W. S. Dawkins, J. J. Devaney, L. T. Devore, J. B. Diaz, R. D. Douglass, R. J. Duffin, J. E. Eaton, F. E. Ehlers, H. J. Ettlinger, B. G. Farley, Eugene Feenberg, Louis Fein, Herman Feshbach, Morton Finston, W. T. Fishback, F. G. Fisher, Alan Fletcher, R. M. Foster, F. H. Fowler, A. H. Fox, Philip Franklin, J. C. Freeman, E. J. Frey, D. L. Fuller, T. S. George, H. A. Giddings, Peter Gilmer, H. E. Goheen, Lawrence Goldmuntz, C. H. Gordon, W. M. Gottschalk, R. E. Graves, L. F. Green, Harry Greenberg, F. T. Haddock, M. E. Haller, J. M. Ham, L. B. Ham, W. H. Hamilton, H. V. Hance, Duncan Harkin, G. G. Harvey, C. M. Hebbert, A. E. Heins, M. J. Herzberger, F. B. Hildebrand, J. A. Hofmann, C. W. Horton, B. E. Howard, G. B. Huff, L. C. Hutchinson, M. D. Indjoudjian, Leopold Infeld, W. J. Jacobi, J $\phi$ rgen Jensen, Miroslav Joachim, Mark Kac, Robert Kahal, M. L. Kales, E. L. Kaplan, Meyer Karlin, E. R. Keown, T. J. Killian, J. R. Kline, Walter Kohn, S. H. Lachenbruch, J. H. Laning, J. P. LaSalle, Y. W. Lee, Alfred Leitner, D. C. Lewis, C. C. Lin, A. N. Lowan, R. B. Lowe, S. C. Lowell, Jerome Lurye, Ingo Maddaus, P. M. Marcus, A. E. Marston, W. T. Martin, L. L. Merrill, David Middleton, M. G. Morgan, S. P. Morgan, H. H. Mostafa, C. C. Nash, Philip Newman, A. A. Oliner, C. H. Papas, N. G. Parke, Philip Parzen, E. K. Paxton, C. L. Pekeris, A. J. Perlis, Arnold Peterson, Hillel Poritsky, R. E. Porter, M. H. Protter, E. G. Ramberg, Robert Rawhouser, C. J. Rees, C. F. Rehberg, Edgar Reich, Eric Reissner, Daniel Resch, R. R. Reynolds, S. O. Rice, J. K. Riess, W. L. Root, J. H. Rosenbloom, V. H. Rumsey, J. P. Russell, Charles Saltzer, M. M. Schiffer, Harold Schutz, H. M. Schwartz, J. F. Scully, C. H. W. Sedgewick, W. W. Seifert, Samuel Sensiper, H. S. Sharp, P. C. Shedd, Herbert Sherman, S. S. Shü, K. M. Siegel, D. N. Silver, T. M. Simpson, George Sinclair, David Slepian, B. D. Smith, J. J. Smith, A. B. Soble, William Sollfrey, R. D. Spence, George Springer, W. D. Stahlman, C. W. Steeg, A. F. Stevenson, S. W. Stewart, J. A. Stratton, D. J. Struik, W. L. Sullivan, W. H. Surber, L. W. Swanson, J. L. Synge, C. T. Tai, A. H. Taub, J. G. C. Templeton, G. B. Thomas, D. L. Thomsen, H. I. Treiber, H. M. Trent, W. J. Trjitzinsky, Rohn Truell, J. W. Tukey, W. G. Tuller, L. A. Van Dyke, A. H. Van Tuyl, A. D. Wallace, Henry Wallman, S. R. Warren, W. H. Watson, G. C. Webber, Herschel Weil, W. G. Welchman, David Wellinger, C. P. Wells, L. R. White, R. M. Whitmer, Norbert 
Wiener, J. E. Wilkins, Henry Wolf, R. A. Woodson, A. W. Wundheiler, W. J. Yost, L. A. Zadeh, M. E. Zaret, D. E. Zilmer, J. W. Zimmer, F. J. Zucker.

The dormitories of The Massachusetts Institute of Technology and the cafeteria and Litchfield Lounge of Walker Memorial Building were available to those attending the Symposium and to their families and their guests.

The Symposium was cosponsored by the American Institute of Electrical Engineers, the American Institute of Physics, and the Institute of Radio Engineers.

Professor J. L. Synge, Chairman of the Committee on Applied Mathematics, presided at the opening session and gave a brief review of the plans for Symposia in Applied Mathematics.

Tea was served by the ladies of the Department of Mathematics of Massachusetts Institute of Technology on Thursday afternoon in Walker Memorial Building.

There were six forty-minute addresses and eleven twenty-minute addresses, all presented by invitation of the Committee on Program and Arrangements. The Symposium was divided into three morning and two afternoon sessions and one evening session. Each paper was followed by a discussion. Owing to the illness of the authors, the paper by Professor R. K. Luneburg of New York University, entitled Asymptotic development of steady solutions of Maxwell's equations based upon discontinuities of pulse solutions, and the paper by Dr. C. E. Shannon of Bell Telephone Laboratories, entitled Theory of the transmission of information, could not be presented.

The seventeen papers were presented in the following order:

1. S. O. Rice, Bell Telephone Laboratories: Reflections from bends and corners in electromagnetic wave guides. (40 minutes)

2. A. E. Heins, Carnegie Institute of Technology: Systems of simultaneous Wiener-Hopf integral equations and their application to some boundary value problems in electromagnetic theory. (20 minutes)

3. J. L. Synge, Carnegie Institute of Technology: Electromagnetism without metric. (40 minutes)

4. E. G. Ramberg, Radio Corporation of America: Aberration correction with electron mirrors. (20 minutes)

5. A. F. Stevenson, University of Toronto: Wave propagation in electromagnetic horns. (20 minutes)

6. Leopold Infeld, University of Toronto: The factorization method and its application to differential equations in theoretical physics. (40 minutes)

7. Eugene Feenberg, Washington University: $A$ method of analyti- 
cal continuation in the eigen-value and scattering problems of quantum theory. (20 minutes)

8. Rohn Truell, Brown University: Problems related to measuring the field strength of high frequency electromagnetic fields. (20 minutes)

9. Herman Feshbach, Massachusetts Institute of Technology: The new quantum electrodynamics. (40 minutes)

10. A. H. Taub, Institute for Advanced Study: Orbits of charged particles. (20 minutes)

11. C. L. Pekeris, Weizmann Institute, Rehovoth, Palestine, and Institute for Advanced Study: Ray theory versus normal mode theory in wave propagation problems. (20 minutes)

12. R. J. Duffin, Carnegie Institute of Technology: Non-linear networks. (20 minutes)

13. Mark Kac, Cornell University: Distribution problems in the theory of random noise. (40 minutes)

14. W. H. Watson, National Research Council of Canada: Discontinuity in electromagnetism. (20 minutes)

15. Henry Wallman, Massachusetts Institute of Technology: Transient response and the central limit theory of probability. (20 minutes)

16. Norbert Wiener, Massachusetts Institute of Technology: Entropy information. (40 minutes)

17. Y. W. Lee, Massachusetts Institute of Technology: The statistical theory of message transmission. (20 minutes)

The presiding officers at the sessions were, respectively: Professors J. L. Synge, J. A. Stratton, P. D. Crout, R. V. Churchill, Dr. H. W. Bode, and Professor R. M. Foster.

At the close of the Saturday afternoon session, a resolution of thanks and appreciation to Massachusetts Institute of Technology for its hospitality was read by Professor J. L. Synge and unanimously approved.

The addresses and papers presented at the Symposium are to be published by the Society in a volume of the Proceedings of the Second Symposium in Applied Mathematics.

W. T. MARTIN

Chairman of the Committee on Program and Arrangements

T. R. HOLLCROFT

Associate Secretary of the Society 